\title{
PERMASALAHAN KRISIS PENDIDIKAN KARAKTER PADA SISWA DALAM PERSPEKTIF PSIKOLOGI PENDIDIKAN
}

\author{
Rabi Yati \\ Email: 2010128120009@mhs.ulm.ac.id \\ Program Studi Pendidikan IPS Fakultas Keguruan dan Ilmu Pendidikan \\ Universitas Lambung Mangkurat \\ Banjarmasin
}

\begin{abstract}
Abstrak
Pendidikan karakter adalah suatu sistem berupa penanaman nilai karakter terhadap peserta didik yang meliputi kemauan atau kesadaran, dan tindakan dalam mengimplementasikan nilai, budi pekerti, karakter, serta akhlak yang baik ke dalam diri peserta didik, yang bertujuan untuk membentuk kepribadian yang baik pada peserta didik seperti jujur, menghormati orang lain, maupun berperilaku baik dalam kehidupan sehari-hari. Pendidikan karakter merupakan hal yang harus diperhaikan terutama didalam perealisasian pendidikan di indonesia, yang mana Indonesia pada masa sekarang mengalami permasalahan-permasalahan yang menyimpang dari nilai, norma dan moral dalam masyarakat, yang mana kebanyakan dari pelaku penyimpangan ini terjadi pada generasi muda terutama pada anak usia sekolah. Dengan melihat fenomena permasalahan krisis nilai, moral dan karakter pada generasi sekarang, ditulislah artikel ini yang bertujuan yntuk mengkaji lebih dalam mengenai pendidikan karakter di sekolah dengan menggunakan pendekatan psikologis pada siswa. Dan dituangkan dengan menggukakan metode deskriptif hingga didapatkan hasil dan dapat ditarik kesimpulan mengenai fenomona tersebut.
\end{abstract}

\section{PENDAHULUAN}

Pendidikan merupakan hal penting dalam suatu negara untuk berkembang menjadi negara maju. Dimana kualitas pendidikan sendiri menjadi salah satu indikator utama dalam melihat suatu negara itu termasuk dalam negara tertinggal, negara berkembang atau negara maju. oleh sebab itu negara-negara di dunia bersaing dalam hal meningkatkan kualitas pendidikan dalam negaranya masing-masing agar tidak menjadi negara yang tertinggal. Pendidikan juga menjadi sarana dalam meningkatkan taraf hidup masyarakat serta sarana dalam mewujudkan cita-cita bangsa yaitu mencerdaskan kehidupan bangsa demi membangun generasi yang membanggakan di masa depan sehingga mampu mengharumkan nama negara (Megawanti, P. 2015).

Di Indonesia sendiri, pendidikan tidak luput dari beberapa permasalahan-permasalahan yang begitu kompleks dan sulit untung ditangani, baik itu dalam hal pembelajarannya, sumber 
daya manusia, inprastruktur hingga yang menjadi pokok permasalahan yang mesti diperhatikan dan menjadi fokus permasalahan pendidikan pada massa sekarang adalah krisis pendidikan karakter pada peserta didik. Dalam membahas mengenai permasalahan pendidikan ini tidak akan pernah ada habisnya terutama dalam hal pendidikan karakter yaitu yang menyangkut pada nilai moral pada peserta didik.

Pendidikan karakter adalah suatu sistem berupa penanaman nilai karakter terhadap peserta didik yang meliputi kemauan atau kesadaran, dan tindakan dalam mengimplementasikan nilai, budi pekerti, karakter, serta akhlak ke dalam diri peserta didik, yang bertujuan untuk membentuk kepribadian peserta didik dalam mengambil keputusan, jujur, menghormati orang lain, maupun berperilaku baik dalam kehidupan sehari-hari (Putra, M. A. H. 2019). Pendidikan karakter ini bisa di dapat melalui beberapa aspek seperti dalam hal agama, orang lain, dorongan diri kita sendiri, maupun lingkungan, terutama pada lingkungan keluarga dan lingkungan sekolah.

Pendidikan karakter merupakan hal yang harus diperhaikan terutama didalam perealisasian pendidikan di indonesia, yang mana Indonesia pada masa sekarang dapat dikatakan telah mengalami krisis karakter atau moral di dalam diri siswa terutama pada siswa yang menginjak usia remaja. Hal ini dikarenakan kurangnya pendidikan karakter pada usia dini dari sekolah maupun dari orang tua sebagai pendidikan pertama yang didapatkan oleh seorang anak ditambah lagi dengan kondisi mental pada anak yang tidak stabil hingga menyulitkan anak dalam hak mengontrol emosi serta kesulitan dalam hal menyaring segala apa yang masuk ke dalam pikiran maupun jiwanya dan mengakibatkan timbulnya pemberontakan, tidak berfikir dulu sebelum bertindak, dan sulit dalam mengontrol emosinya.

Dengan melihat fenomena permasalahan krisis karakter pada peserta didik tersebut, ditulislah artikel ini yang bertujuan yntuk mengkaji lebih dalam mengenai penyebab terjadinya krisis moral dan karakter serta sulusi dalam menghadapi krisis pendidikan karakter ini pada siswa dengan pendidikan karakter. dengan menggunakan metode deskriptif serta metode studi literatur mengenai pendidikan karakter dan psikologi yang di dapat dari beberapa jurnal atau artikel-artikel penelitian terdahulu sehingga didapatkan hasil pembahasan dan dapat ditarik kesimpulan mengenai suatu fenomena permasalahan krisis pendidikan karakter ini.

\section{METODE}

Metode yang digunakan dalam penulisan artikel ini adalah menggunakan metode desktiptif. Dimana metode ini menggambarkan suatu fenomena mengenai permasalahan pendidikan karakter siswa ke dalam bentuk definisi atau pengertian yang didapat berdasarkan 
dari fakta-fakta atau ralitas yang benar benar terjadi di dalam pendidikan Indonesia. Adapun untuk pengumpulan data-data yang terdapat di dalam artikel ini menggunakan studi kepustakaan atau studi literatur dari jurnal-jurnal atau artikel-artikel penelitian terdahulu sehingga terjami keakribilitasannya. Sehingga dari data-data yang dikumpulkan tersebut lalu di rekonstruksi ulang sehingga mendapatkan hasil dan dapat ditari kesimpulan dari rumusan masalah dan yang ditujukan.

\section{HASIL DAN PEMBAHASAN}

\section{Konsep Pendidikan Karakter}

Nilai karakter merupakan hal yang sangat penting dalam kehidupan bermasyarakat, yang akan membentuk suatu kepribadian yang baik dalam diri seseorang. Dimana nilai karakter yang baik ini dapat diwujudkan dalam bentuk segala ucapan maupun tindakan yang sejalan dengan norma-norma serta nilai-nilai yang berlaku di dalam masyarakat. Oleh karena itu pendidikan karakter sangat diperlukan untuk penaman nilai-nilai baik dan moral yang baik kepada masyarakat, dimana pendidikan karakter ini bisa didapatkan di lingkungan keluarga (orang tua), lingkungan sekolah, pergaulan, dan lingkungan sosialnya.

Pendidikan karakter adalah suatu sistem berupa penanaman nilai karakter terhadap peserta didik yang meliputi kemauan atau kesadaran, dan tindakan dalam mengimplementasikan nilai, budi pekerti, karakter, serta akhlak yang baik ke dalam diri peserta didik, yang bertujuan untuk membentuk kepribadian peserta didik dalam mengambil keputusan, jujur, menghormati orang lain, maupun berperilaku baik dalam kehidupan seharihari (Putra, M. A. H. 2019). Pendidikan karakter merupakan suatu upaya dalam mengembangkan perilaku yang baik dalam sehari-haru agar peserta didik dapat mencerminkan sebuah karekter yang baik pada dirinya (Uliana, P. 2013).

Penanaman nilai-nilai karakter dapat dibentuk melalui adanya pendidikan kan karakter dalam lingkungan keluarga, pergaulan dan lingkungan sekolah. Pendidikan karakter yang terdapat di lingkungan sekolah disesuaikan dengan tujuan pendidikan itu sendiri yang telah tercantum dalam UU No.23 Tahun 2003 mengenai Sistem Pendidikan Nasional yang terdapat pada pasal 3 yang menjelaskan bahwa pendidikan nasional memiliki fungsi dalam hal pengembangan kemampuan dan pembentukan watak atau karakter serta peradaban bangsa yang memiliki martabat dalam rangka mencerdaskan kehidupan anak bangsa, dan untuk perkembangan potensi siswa agar menjadi seseorang yang memiliki iman dan bertakwa kepada Tuhan yang Maha Esa, berakhlak mulia, berilmu, cakap, sehat, mandiri, kreatif dan menjadi seorang warga yang memiliki sifat demokratis juga bertanggung jawab. Oleh karena itu 
pendidikan karakter ini sangat di foskuskan di dalam lingkungan sekolah yang tersisipkan dalam pembelajaran oleh pendidik, demi mencetak anak bangsa yang memiliki akhlak serta budi pekerti yang baik di dalam dirinya.

Dalam pendekatan psikologi penanaman pendidikan karakter di sekolah didukung dengan adanya aktifitas-aktifitas positif yang akan membangun nilai-nilai karakter serta moral yang baik pada peserta didik dengan pemberian strategi pembelajaran tertentu seperti membangun hubungan dan interaksi yang baik di dalam kelas baik dengan teman-temannya maupun dengan guru, dimana hubungan sosial ini lah yang begitu mempengaruhi dalam hal penanaman nilai moral di lingkungan kelas. Selain itu pendidikan karakter dan moral pada peserta didik sangat diperlukan adanya peran pendamping sebagai pembimbing baginya agar nilai-nilai karakter itu tertanamkan dengan kuat. Oleh karena itu keterlibatan dari orang-orang terdekat seperti orang tua ini menjadi peran yang begitu penting dalam pembangunan karakter dan moral pada anak, karena pada dasarnya pendidikan pertama yang didapat oleh anak itu berasal dari orang tuanya. Bawaan karakter dari keluarga yang dibangun dari rumah juga menjadi perhatian khusus dalam pembangunan karakter juga emosi seoranng anak, karena karakter bawaan dari sang anak inilah yang akan ditunjukkan seorang anak dalam menunjukkan emosinya saat bersosialisasi di kehidupan sehari-harinya dan karakter dan emosi bawaan ini juga akan dibawanya ke daalam lingkungan sekolah.

Untuk mewujudkan pelaksanaan pendidikan karakter yang akan mencetak peserta didik untuk memiliki nilai, moral, serta budi pekerti baik, diperlukan kerjasama yang baik antara orang tua siswa dan guru dalam menanamkan pembelajaran-pembelajaran moral terhadap siswa. Karena penanaman nilai karakter disekolah dimulai dari pendidikan moral dan penanaman nilai-nilai yang diberikan oleh orang tuanya terlebih dahulu di rumah sehingga guru hanya perlu meningkatkan atau mengembangkannya lagi di dalam lingkungan sekolah. Dalam pendidikan karakter disekolah, guru lah yang meiliki peran besar dalam penanaman nila-nilai budi pekerti kepada siswa karena peran guru yang strategis, yaitu sebagai pendidik juga pemimpin dalam jalannnya pembelajaran dalam kelas, sehingga yang dapat melakukan penanaman nilai, moral serta budi pekerti secara langsung adalah guru karena gurulah yang sering melakukan interaksi dengan peserta didik dan menuangkan nilai moral serta budi pekerti ke dalam aktivitas pembelajaran yang dilakukan di dalam kelas.

\section{Permasalahan Krisis Moral dan Pendidikan Karakter}

Begitu banyak terjadi permasalahan di negara kita ini yang telah mengakar dan sulit untuk di tanggani. Salah satu permasalahan yang telah menjadi perhatian pemerintah yang 
semakin meningkat pada masa sekarang adalah permasalahan-permasalahan yang menyimpang dari nilai, norma dan moral dalam masyarakat, yang mana kebanyakan dari pelaku penyimpangan ini terjadi pada generasi muda terutama pada anak usia sekola. Adapun penyebab terjadinya permasalahan-permasalahan yang menyimpang tersebut adalah karena krisis nilai karakter dan moral yang dialami oleh masyarakat dikarenakan kurangnya kesadaran dalam diri masyarakat maupun kurangnya pendidikan karakter yang didapat. Hal inilah yang kemudian membuat pemerintah semakin gencar lagi dalam menjadikan pendidikan karakter sebagai bagian besar dari pembelajaran yang ditanamkan kepada siswa dalam lingkungan sekolah.

Permasalahan-permasalahan yang menyimpang dari nilai, norma dan moral di negara ini antara lain 1) permasalahan korupsi, kolusi dan nepotisme; 2) kejahatan atau kriminalitas yang tinggi; 3) pelecehan seksual; 4) perundungan atau bulliying; 5) kekerasan dalam rumah tangga; 6) pelecehan seksual; 7) kecanduan obat-obatan terlarang 8) hamil diluar nikah yang mengakibatkan tingginya pernikahan pada anak dibawah umur 9) kenakalan remaja, dan lainlain.

Melihat krisis nilai moral serta budi pekerti pada masa sekarang tentunya sangat memprihatinkan bagi kita sebagai warga negara Indonesia, karena kebanyakan penyimpangan ini terjadi kepada anak dengan usia sekolah, dimana generasi inilah yang kelak menjadi harapan bangsa dalam memimpin negara di masa yang akan datang. Sehingga pemerintah lebih giat lagi di dalam pembangunan kembali pendidikan karakter yang ada di sekolah. Pendidikan karakter di sekolah ini bertujuan untuk menekan serta menghindari krisis moral pada peserta didik sehingga mereka sebagai penerus bagsa tahu betul bagaimana caranya bertidak sesuai dengan norma dan moral yang berlaku dalam masyarakat.

Dalam hal penyebab dari terjadinya pelanggaran-pelanggaran atau penyimpangan yang terjadi pada nilai dan norma ini dapat dikatakan karena beberapa faktor, yakni kondisi lingkungan, pergaulan, psikologis serta emosional yang aterjadi pada seorang anak lah yang menjadikan penyimpangan ini banyak terjadi dalam usia anak sekolah terutama pada usia remaja, dimana remaja memiliki emosi serta psikologis yang cendrung kurang stabil, hal ini dikarenakan dalam usia remaja mereka masih dalam tahap pencarian jati diri dan belum menemukan siapa dan akan menjadi apa mereka. Sehingga kebanyakan anak pada usia sekolah lebih rantan terbawa akan emosi, tidak berfikir dulu debelum bertindak atau bersikap nekat, suka mencoba hal-hal baru dan kurang bisa memfilter apa yang baik dan yang buruk bagi diriya. 
Selain beberapa faktor tersebut, faktor pembawaan karakter dan pisikologis yang didapat dari didikan orang tua di dalam rumah yang menjadi tempat dimana ia menghabiskan banyak wakju juga memiliki ambil besar dalam pembangunan serta penanaman nilai karrakter dari seorang anak. Dimana pendidikan karakter itu pertamakali didapatkan dari orang tuanya sampai ia menginjak usia sekolah pun orang tua tetap menjadi pendamping utama dalam penanaman nilai-nilai karakter serta moral pada anak.

Dengan melihat betapa pentingnya pendidikan karakter inilah yang kemudian mendorong pemerintah untuk menjadikan pembentukan katakter menjadi salah satu tujuan di dalam pendidikan yang telah ditetapkan dalam Undang-Undang No.23 Tahun 2003 mengenai Sistem Pendidikan Nasional pada pasal 3, yang mana hal ini kemudian dapat dilihatdalam pelaksanaan pembentukan karakter di sekolah dilakukan penanaman nilai-nilai budi pekerti dan moral melalaui beberapa sisipan dari aktivitas pembelajaran-pembelajaran yang berlangsung di dalam kelas.

\section{SIMPULAN}

Melihat krisis nilai moral serta budi pekerti pada masa sekarang tentunya sangat memprihatinkan bagi kita sebagai warga negara Indonesia, karena kebanyakan penyimpangan ini terjadi kepada anak dengan usia sekolah. Sehingga pemerintah lebih giat lagi di dalam pembangunan kembali pendidikan karakter yang ada di sekolah. Pendidikan karakter adalah suatu sistem berupa penanaman nilai karakter terhadap peserta didik yang meliputi kemauan atau kesadaran, dan tindakan dalam mengimplementasikan nilai, budi pekerti, karakter, serta akhlak ke dalam diri peserta didik, yang bertujuan untuk membentuk kepribadian peserta didik

Dalam pendekatan psikologi penanaman pendidikan karakter di sekolah didukung dengan adanya aktifitas-aktifitas positif yang akan membangun nilai-nilai karakter serta moral yang baik pada peserta didik dengan pemberian strategi pembelajaran tertentu seperti membangun hubungan dan interaksi yang baik di dalam kelas baik dengan teman-temannya maupun dengan guru. Bawaan karakter dari keluarga yang dibangun dari rumah juga menjadi perhatian khusus dalam pembangunan karakter juga emosi seoranng anak, karena karakter bawaan dari sang anak inilah yang akan ditunjukkan seorang anak dalam menunjukkan emosinya saat bersosialisasi di kehidupan sehari-hari.

pelanggaran-pelanggaran atau penyimpangan yang terjadi pada nilai dan norma ini dapat dikatakan karena beberapa faktor, yakni kondisi lingkungan, pergaulan, psikologis serta emosional yang aterjadi pada seorang anak lah yang menjadikan penyimpangan ini banyak 
terjadi dalam usia anak sekolah terutama pada usia remaja, dimana remaja memiliki emosi serta psikologis yang cendrung kurang stabil.

\section{REFERENSI}

Abbas, E. W. (2013). Ersis Warmansyah Abbas. PENDIDIKAN KARAKTER, 19.

Abbas, E. W. (2019). Building Nation Character Through Education: Proceeding International Seminar on Character Education.

Afandi, R. (2011). Integrasi pendidikan karakter dalam pembelajaran IPS di sekolah dasar. PEDAGOGIA: Jurnal Pendidikan, 1(1), 85-98.

Amelia, R., Putro, H. P. N., \& Permatasari, M. A. (2020). The Role of Caregivers as a Social Attitude Developer in The Children's Social Homes Budi Mulia Banjarbaru. The Kalimantan Social Studies Journal, 2(1), 56-61.

Dewi, N. L. L. A., Putrayasa, I. B., \& Nurjaya, I. G. (2014). Analisis Nilai-Nilai Pendidikan Karakter Novel Sepatu Dahlan Karya Khrisna Pabichara dan Relevansinya terhadap Pengajaran Pendidikan Karakter Sekolah di Indonesia. Jurnal Pendidikan Bahasa dan Sastra Indonesia Undiksha, 2(1).

Diananda, A. (2019). Psikologi remaja dan permasalahannya. ISTIGHNA: Jurnal Pendidikan dan Pemikiran Islam, 1(1), 116-133.

Dwiningrum, S. I. A., \& Purbani, W. (2012). Manusia berkarakter dalam perspektif guru dan siswa. Jurnal Kependidikan: Penelitian Inovasi Pembelajaran, 42(1).

Komara, E. (2018). Penguatan pendidikan karakter dan pembelajaran abad 21. Sipatahoenan, $4(1)$.

Hermino, A. (2015). Pendidikan Karakter dalam Perspektif Psikologis Siswa Sekolah Menengah Pertama di Era Globalisasi dan Multikultural. Jurnal peradaban, 8, 19-40.

Ilmiyannor, M., \& Mi'rajiatinnor, D. (2021, February). Strengthening Environmental Care Attitudes Through Social Wisdom-Based Social Studies Learning. In The 2nd International Conference on Social Sciences Education (ICSSE 2020) (pp. 65-69). Atlantis Press.

Indriyani, I. E., Syaharuddin, S., \& Jumriani, J. (2021). Social Interaction Contents on Social Studies Learning to Improve Social Skills. The Innovation of Social Studies Journal, 2(2), 93-102.

Julaeha, S. (2019). Problematika Kurikulum Dan Pembelajaran Pendidikan Karakter. Jurnal Penelitian Pendidikan Islam,[SL], 7(2), 157-182. 
Megawanti, P. (2015). Meretas Permasalahan Pendidikan Di Indonesia. Formatif: Jurnal Ilmiah Pendidikan MIPA, 2(3).

Mutiani, M., Sapriya, S., Handy, M. R. N., Abbas, E. W., \& Jumriani, J. (2021). Pembinaan Etika Peserta Didik Melalui Pembelajaran Tematik-Integratif Di Sekolah Dasar. Edukatif: Jurnal Ilmu Pendidikan, 3(3), 704-709.

Uliana, P. (2013). Implementasi pendidikan karakter melalui kultur sekolah pada siswa kelas XI di SMA Negeri 1 Gedangan Sidoarjo. Kajian Moral dan Kewarganegaraan, 1(1), 165-179.

Prastowo, A. (2014). Pemenuhan kebutuhan psikologis peserta didik SD/MI melalui pembelajaran tematik-terpadu. Jurnal Pendidikan Sekolah Dasar Ahmad Dahlan, 1(1), $1-13$.

Putra, M. A. H. (2019). Building Character Education Through The Civilization Nations Children. The Kalimantan Social Studies Journal, 1(1), 12-17.

Putro, H. P. N., Wahyu, W., Subiyakto, B., Arisanty, D., \& Anis, M. (2019). Peningkatan Pemahaman Guru Mengenai Pembelajaran Saintifik Pada Kurikulum 2013 Bagi Guru MTs Provinsi Kalimantan Selatan.

Rahayu, R., Abbas, E. W., \& Jumriani, J. (2021). Social Studies Lesson Planning for Children with Intellectual Disabilities in the Pembina State Special School of South Kalimantan Province. The Kalimantan Social Studies Journal, 2(2), 160-169.

Sakerebau, J. (2018). Memahami Peran Psikologi Pendidikan Bagi Pembelajaran. BIA': Jurnal Teologi dan Pendidikan Kristen Kontekstual, 1(1), 96-111.

Syaharuddin, S., Samihati, M., \& Jumriani, J. (2020). AKTUALISASI SIKAP PEDULI LINGKUNGAN MELALUI AKTIVITAS PENGELOLAAN SAMPAH. Jurnal Socius, 9(2), 193-203. 